14-16 May, 2021

Paris, France

\title{
The Value of the Public Sector Governance
}

\author{
Georgia Tsagdi
}

PhD candidate, Athens University of Economics and Business, Greece

\begin{abstract}
.
Public sector governance constitutes a focal point in the public debate, as it relates directly with public entities' accountability and citizens' expectations for effectiveness and quality of the public services. Despite its numerous citations, the concept of "public sector governance" is relatively new and a direct transfer of the most common corporate governance principles does not suffice, as totally different actors, stakeholders and interests prevail. Aim of this paper is to present a conceptual framework that examines key constituents of public sector governance theories, mostly in the context of the public value paradigm, emphasizing the role of the political environment.
\end{abstract}

Keywords: public value, political control, governance.

\section{Evidence for Practice}

- The current Greek economic crisis is accentuating the need to have reliable evidence of which policies and control systems work for the public sector.

- Public value has always been a challenging notion to define and measure.

- This article sheds new light on the public value theory and framework by bringing to the forefront the political context within which public value is created.

\section{Introduction}

Public sector governance constitutes a focal point in the public debate, as it relates directly with public entities' accountability and citizens' expectations for effectiveness and quality of the public services. Despite its numerous citations, the concept of "public sector governance" is relatively new not only within the circles of public sector administrators but also within academia.

A direct transfer of the most commonly used definitions and research might serve as a good starting point in the study of public sector governance. This however could not suffice due to the fact that corporate governance definitions elevate the role of shareholders and stock market and thus render themselves inappropriate for use within the context of public sector 


\section{$12^{\text {th }}$ International Conference on Modern Research in \\ MANAGEMENT, ECONOMICS and ACCOUNTING}

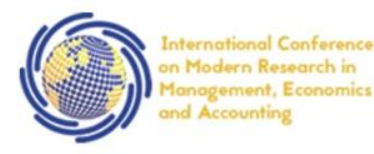

\section{4-16 May, 2021 \\ Paris, France}

administration. For the purposes of the proposed project, we have to emphasize public interest, multiple stakeholders and more ambiguous objectives not settled in a capital market.

From this perspective, "good" public sector governance is viewed not only as good performance in terms of achievement of a set of objectives, but also as compliance with the requirements deriving from policies and reforms, laws and regulations, standards and procedures and the expectations of citizens for transparency, integrity, and accountability.

\section{Research aim}

Research on the topic of "public sector governance" is still in its infancy, as demonstrated by the scarcity of literature and empirical studies. The proposed article aims to cover part of the gap within the field of public sector governance research, through the examination of the following questions: What are the key constituents of public sector governance? What are the factors that affect it and which is their direct and/or combined impact on the performance of a public organization? Is there a "right mix" of hard and soft factors that leads to good public sector governance?

Further to the examination of its key constituents, the context within which public sector governance is formulated and enacted, plays a key role in its interaction with performance, and with governance itself. For this reason, an additional aim of the proposed project is to examine the impact of specific attributes of the external environment, such as policies and reforms, as well as the impact of internal resources and capabilities of the public organization itself, including its structure and autonomy.

In the following sections we give an outline of the attributes of the public sector governance, and the characteristics of the public organization as well as of the external environment that influence the value that will be created within a public organization.

\section{Research propositions and conceptual framework}

Public value theory, the main research theory of our model, has despite its significance, received notable criticism for advancing a normative paradigm rather than an empirical theory (Barzelay 2007, Rhodes and Wanna 2007).Big part of this criticism is due to the difficulty of measuring public value: difficulties in registering revealed and stated preferences, inability to determine what is valuable in absolute terms, dealing with protected values that are quantity insensitive and agent relative, determining the users of public value and encompassing in its measurement not only outputs but also outcomes. In this process, several policy analysis tools and methods have been proposed such as the cost -benefit or program evaluation analysis, the travel cost model, the public value scorecard the willingness to pay (WTP) and willingness to accept (WTA) methodologies. However, while adding fuel to the debate, they fail to capture the intentions of Moore's public value approach (Alford \& O' Flynn 2009) and most 


\section{$12^{\text {th }}$ International Conference on Modern Research in \\ MANAGEMENT, ECONOMICS and ACCOUNTING}

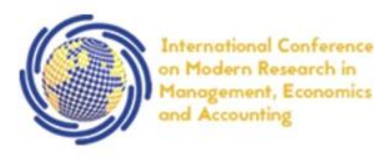

\section{4-16 May, 2021 \\ Paris, France}

importantly to acknowledge the significance of the political environment, that can be a legitimization factor or a legitimate limit to the autonomy to create public value.

In the proposed study, drawing from the main public value theorists (Moore 1995, Kelly, Mulgan, and Muers 2002) we identify seven basic building blogs of the public value framework - Social Outcomes, Trust, Transparency, Legitimacy, Service competency and Customer Satisfaction and Citizens co-production, by adopting appropriate conceptualizations. By setting this research agenda we wish to test our framework and highlight the key challenges and limitations that this framework faces and more importantly explore the impact that specific organizational attributes of the public organizations have in the creation of public value. All of these within a certain political context.

\subsection{Research propositions}

3.1.1 Feeling trusted by the central government and having strong political ties but less political control is strongly associated for supervised authorities, with the value they create and have for the citizens. Literature so far suggests that bureaucracies are highly responsive to political forces (Redford 1969, Wood 1988, Aldirich \& Fiol 1994, Hillman et al.,1999). More specifically, whenever there is elected official support, mostly expressed as trust to the organization, political involvement has proved to be considerably low (Daft and Lengel 1986, Kirkhaug \& Mikalsen 2009). In addition, political ties, mediated by organizational regulatory legitimacy, affects firm performance (Guo, et al., 2014, Okhmatovskiy, 2010). Also, a strong relation between political ties and corporate transparency has been many times acknowledged (Leuz et.al., 2006) and there is a strong link between political behaviours, outcomes and trust (Daniel \& Snow 2000, Farrell \& Petersen,1982).

3.1.2 Intra-organizational trust is associated with increased public value creation. Central to our model is the concept of trust built within the organization. Lately trust has started gaining wide acceptance in the literature as a means for improving efficiency (Culbert \& McDonough 1986, Hitt et al., 2003) Nevertheless there is scarce research that connects interfirm trust with elected officials trust towards the organization and trust created in the public value context.

3.1.3 Participative decision making with "clients"- citizens, is strongly associated with the political control that is exerted over a supervised authority and is also linked to the creation of public value within an organization. Participative decision making is strongly associated with the level of trust within an organization (Gabris \& Kenneth, 1986, Carnevale \& Wechsler, 1992), transparency (Welch, 2012), organizational performance (Lam et al., 2002, Wang 2001) and outcomes (Coopman, 2001). Also, it is highly influenced by external stakeholders, turbulent or politicized environments (Welch, 2012). Therefore, it can be a key driver for the creation of public value

3.1.4 The structure of an organization is strongly associated with the value that the organization has for all citizens. Further to participative decision making, autonomy and red tape, another important characteristic of a public entity is its structure, in our case whether it is an organic or a mechanistic one (Turner \& Makhija,2012). Structural features such as 


\section{$12^{\text {th }}$ International Conference on Modern Research in \\ MANAGEMENT, ECONOMICS and ACCOUNTING}

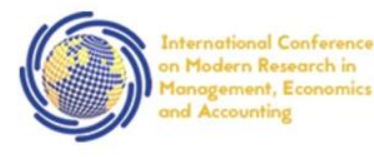

\section{4-16 May, 2021 \\ Paris, France}

hierarchical decision making or centralization, affect service satisfaction (Meirovich et al.2002) and hierarchical authority is almost linearly associated participation outcomes (Yang \& Pandey,2011). Technocratization and administrative density are strongly associated with the creation of public value in an organization.

3.1.5 Technocratization and administrative density, i.e., the level of formal technical and scientific competence of the organization and the ratio of the number of line supervisors, managers, and staff personnel to the total number of employees, are strongly associated with the efficiency of an organization (Khandwalla 1977, Miller 1987) and may also be result of political patronage. Theoretical research of these two variables and their associations is still quite limited in spite of important empirical indications. This study aims at further exploring these two topics and how they affect the public value created in an organization, thus contributing hopefully to a new stream of research

3.1.6 The level of autonomy of an organization is strongly associated with the creation of public value in an organization and the political control that is exerted. In the literature on governance one can also find ample evidence of the strong relationship between political control exerted in a public organization and its level of autonomy (Christensen \& Laegreid 2004, Verschuere 2007). Granting autonomy to public administrators is also largely perceived as a way of improving service efficiency in an organization by - inter alia - halting politicians from interfering in the everyday management (Jorgensen 1991; Wise 2002). In the present study we examine the policy, personnel and financial management autonomy of the organization.

3.1.7 The level of red tape that exists within an organization is strongly associated with the political control that is exerted and the value that this organization will have at the end for its clients and citizens.

3.1.8 Many researchers have talked about the political control of the bureaucracy (Wood \& Waterman 1994, Balla 1998, Bozeman 1987, Meier 1987, Rainey 2003, Waterman et al., 2004) especially from an agency's theory perspective. Politics in general has been found to have a big impact on public organizations (Dahl \& Lindblom 1953, Meier 1987, Wilson 1989), but research has focused more on the political aspects of the phenomenon and less on its organizational manifestations. In the present study we focus not only on the implications of the political environment and political ties that exists between bureaucrats and politicians but we seek to see the effect that red tape has in the creation of public value in an organization.

A graphic representation of the conceptual model, where we can see the three different entities-actors and their specific attributes we examine, is provided below.

Figure 1: conceptual model 
14-16 May, 2021

\section{Paris, France}

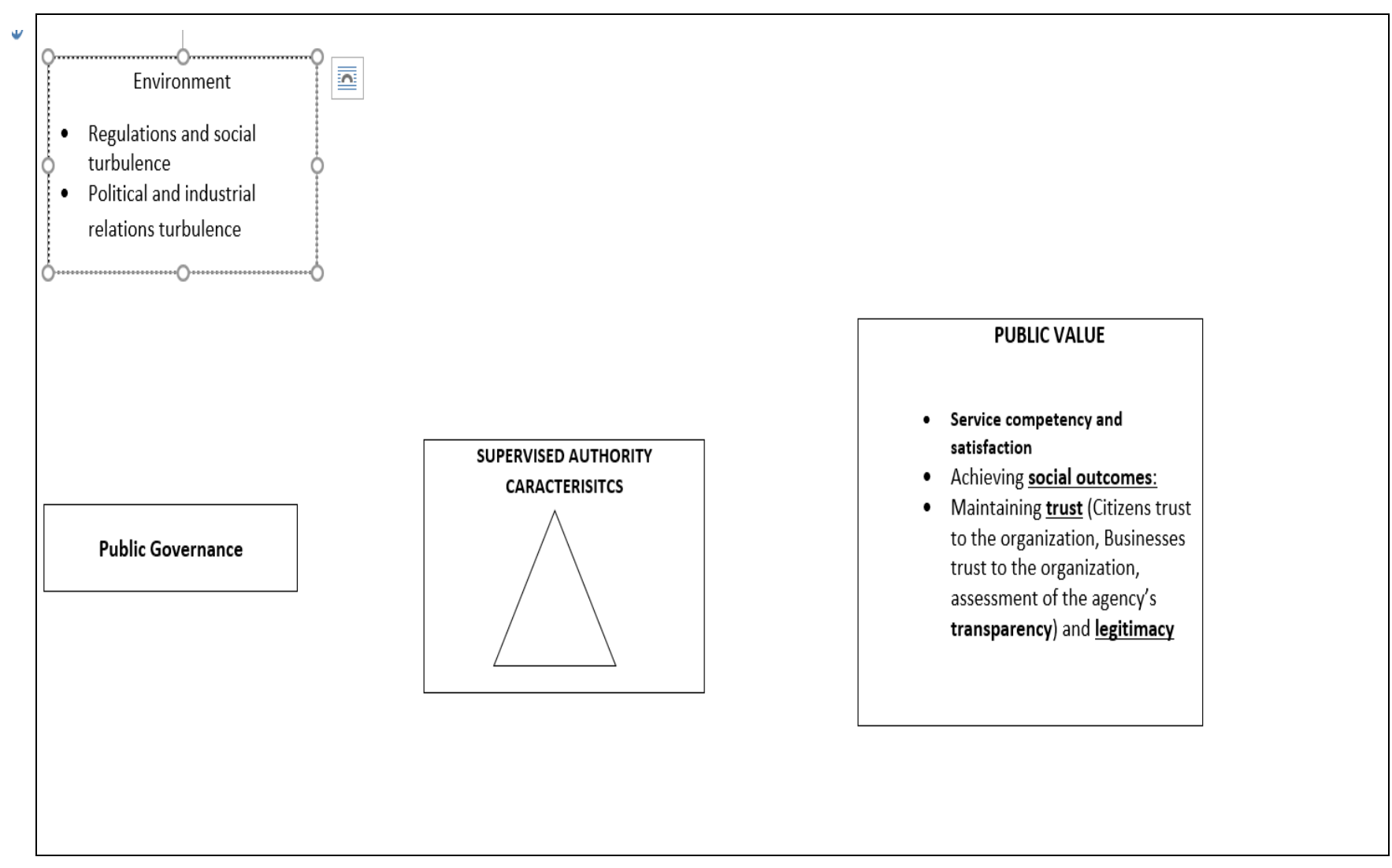

\subsubsection{The role of the external environment}

Previous research has also demonstrated that the scope and intensity of the relationship between politics and administration is strongly affected by environmental as well as organizational factors (Jacobsen 2006). Rapidly changing regulatory environments and unpredicted social demands may increase the need for consultations between politicians and administrators (Mintzberg 1989) and turbulent industrial relations (strikes, work stoppages and inter-trade union conflicts) can foster the need to address this unbalance of power with increased political support and control (Kirkhaug \& Mikalsen 2009). Technological turbulence is also found to moderate the relationship between political ties and firm performance (Sheng, et al.,2011). Lastly, environmental changes in the regulatory framework strongly affect organizational legitimacy (He \& Baruch, 2010). 


\section{$12^{\text {th }}$ International Conference on Modern Research in \\ MANAGEMENT, ECONOMICS and ACCOUNTING}

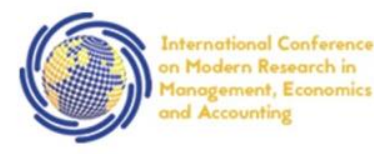

\section{4-16 May, 2021 \\ Paris, France}

\section{Conclusion}

In this paper, we have proposed a contextualized framework that includes the political control that is exerted to a public entity, supervised by the central government in the Greek public sector. In addition, we have focused on some specific organization characteristics that we believe are mostly affected by the aforementioned political control but will also impact the value created in that organization for citizens. So far, exploring what makes an organization more efficient and what will make an organization valuable for its clients, has often been built in the literature, on theories borrowed from the private sector. The public value theory is criticized for being particularly vague and mostly normative. Attempts to measure public value have crushed because of the many different actors and perspectives that need to be considered.

We have attempted to take a step back and looked at the literature as a whole to try to find not only which are the main aspects of what we call "public value" and expand the new public management and public value theories, integrating elements of both of them into a broader paradigm that emphasizes the political context in which public organizations operate in. Our approach we believe paves the way for future studies seeking to broaden the scope of the public value paradigm, both theoretically and empirically. Future research could find ample empirical evidence and carefully analyse how the policy system should address the questions and opportunities that arise.

\section{References}

1. Alexiou, K. and Wiggins J. (2019). "Measuring individual legitimacy perceptions: Scale development and validation" Strategic Organization, vol.17, pp. 470-496.

2. Andrews, R. and Van de Walle, S. (2012). "New Public Management and Citizens' Perceptions of Local Service Efficiency, Responsiveness, Equity and Effectiveness." Public Management Review, vol.15, pp. 762-783

3. Antonsen, M., and Beck Jorgensen, T. (1997). "The Publicness of Public Organizations" Public Administration, vol.75, pp. 337-57.

4. Bolívar Ramos, M. T., García Morales, V. J., \& García Sánchez, E. (2012). “Technological distinctive competencies and organizational learning: Effects on organizational innovation to improve firm performance." Journal of Engineering and Technology Management, vol.29, pp. 331-357.

5. Bortolotti, T., S. Boscari, and P. Danese. (2015). "Successful Lean Implementation: Organizational Culture and Soft Lean Practices.", International Journal of Production Economics vol.160, pp.182-201.

6. Clauss, T. (2017). "Measuring business model innovation: conceptualization, scale development, and proof of performance," $R \& D$ Management, vol. 47, pp. 385-403. 
$12^{\text {th }}$ International Conference on Modern Research in

MANAGEMENT, ECONOMICS and ACCOUNTING

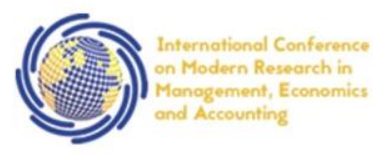

\section{4-16 May, 2021}

Paris, France

7. Coursey, D., K. Yang, and Pandey S. (2012). "Public Service Motivation (PSM) and Support for Citizen Participation: A Test of Perry and Vandenabeele's Reformulation of PSM Theory," Public Administration Review vol.72, pp.572-582.

8. Danneels, E. (2008). "Organizational antecedents of second-order competences," Strategic Management Journal, vol.29, pp.519-543.

9. De Clercq, D., Thongpapanl, T., \& Dimov, D. (2011). "A closer look at cross-functional collaboration and product innovativeness: Contingency effects of structural and relational context," Journal of Product Innovation Management, vol. 28,pp. 680-699.

10. Douglas, S., and Meijer A. (2016). "Transparency and Public Value-Analyzing the Transparency Practices and Value Creation of Public Utilities, " International Journal of Public Administration,vol.39,pp. 940-951.

11. Ghoshal, S. and Bartlett C. A. (1988), "Creation, adoption, and diffusion of innovation by subsidiaries of multinational corporations," Journal of International Business Studies, vo.19, pp. 365-388.

12.Gremler D.D., Gwinner.P.K., (2000), "Customer-Employee Rapport in Service Relationships," Journal of Service Research, vol.3 pp.82-104.

13. House, R.J., Hanges, P.J., Javidan, M., Dorfman,P.W., Gupta,V. (2004),Culture, Leadership, and Organizations: The GLOBE Study of 62 Societies. Sage Publications, Thousand Oaks, CA.

14. Henard, D. H., and P. A. Dacin. (2010). "Reputation for product innovation: Its impact on consumers," Journal of Product Innovation Management, vol.27, pp.321-35.

15. Hoque, Z., \& Hopper, T., 1997). "Political and industrial relations turbulence, competition and budgeting in the nationalized jute mills of Bangladesh." Accounting and Business Research, vol.27, pp. 125-143.

16. Jabeen, F., \& Isakovic, A. (2018). "Examining the impact of organizational culture on trust and career satisfaction in the UAE public sector: A competing values perspective." Employee Relations, vol.40, pp.1036-1053.

17. Jung, K., \& Moon, M. (2007). "The double-edged sword of public-resource dependence: The impact of public resources on autonomy and legitimacy in Korean cultural nonprofit organizations." The Policy Studies Journal, vol.35, pp.205-226.

18. Kaptein M.,(2008). "Developing and testing a measure for the ethical culture of organizations: The corporate ethical virtues model," Journal of Organizational Behavior vol.29,pp.923-947.

19. Kirkhaug, R., and Mikalsen. K. H. (2009.) "Coping with Autonomy: Antecedents of Interaction between Bureaucrats and Politicians," Public Management Review vo.11, pp. 137-154. 


\section{4-16 May, 2021 \\ Paris, France}

20. Lonti, Z. (2005). "How much decentralization? Managerial autonomy in the Canadian public service," American Review of Public Administration, vol.35,pp.122-136.

21. Lu, Y., Ramamurthy, K., (2011). "Understanding the link between information technology capability and organizational agility: an empirical examination," MIS Quarterly vol.35, pp.931-954.

22. Matute, J., Bravo, R., \& Pina, J. M. (2010). “The influence of corporate social responsibility and price fairness on customer behaviour: Evidence from the financial sector," Corporate Social Responsibility and Environmental Management, vo.18, pp.317331.

23. Meznar, M. B. and Nigh, D. (1995). "Buffer or bridge? Environmental and organizational determinants of public affairs activities in American firms," Academy of Management Journal, vol.38,pp. 975-96.

24. Muijen, J.J.V., Koopman, P., Witte, K.D., Cock, G.D., Susanj, Z., Lemoine, C., Bourantas, D.,Papalexandris, N., Branyicsk, I., Spaltro, E., Jesuino, J., Gonzalves Das Neves, J., Pitariu, H.,Konrad, E., Peiro', J., Gonza'lez-Roma', V. and Turnipseed, D. (1999). "Organizational culture: the focus questionnaire." European Journal of Work and Organizational Psychology, vol. 8, pp. 551-68.

25. Moynihan, Donald P., and Sanjay K. Pandey. (2007). "The Role of Organizations in Fostering Public Service Motivation,” Public Administration Review vol.67,pp.40-53.

26. Ordanini, A. and Parasuraman, A. (201). "Service innovation viewed through a servicedominant logic lens: a conceptual framework and empirical analysis," Journal of Service Research, vol. 14, pp. 3-23.

27. Parrado, S., Gregg G., Van Ryzin, G., Bovaird T. and Loeffl E. (2013). "Correlates of CoProduction: Evidence from a Five-Nation Survey of Citizens," International Public Management Journal vol. 16, pp. 85-112.

28. Podsakoff, P. M., MacKenzie, S. B., Moorman, R. H. and Fetter, R. (1990.) "Transformational leader behaviors and their effects on followers' trust in leader, satisfaction, and organizational citizenship behaviors," Leadership Quarterly, vol.1, pp.107-142.

29. Reimann, B. C., (1973). "On the Dimensions of Bureaucratic Structure: An Empirical Reappraisal," Administrative Science Quarterly vol.18, pp. 462-476.

30. Salamon, S., \& Robinson, S. (2008). "Trust that binds: The impact of collective felt trust on organizational performance, ” Journal of Applied Psychology, vol.93, pp.593-601.

31. Singh, J., de los Salmones Sanchez, M. and del Bosque, I. R. (2008). "Understanding corporate social responsibility and product perceptions in consumer markets: a cross-cultural evaluation," Journal of Business Ethics, vol.80,pp 597-611.

32. Turner, K.L., Makhija, M.V., (2012). "The role of individuals in the information processing perspective," Strategic Management Journal, vol 33, pp.661-680. 


\section{$12^{\text {th }}$ International Conference on Modern Research in \\ MANAGEMENT, ECONOMICS and ACCOUNTING}

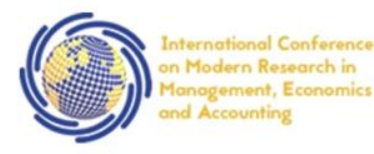

\section{4-16 May, 2021 \\ Paris, France}

33. Verschuere, B. (2007.) "The autonomy-control balance in Flemish arm's length public agencies," Public Management Review, vol.9 pp. 107-133

34. Verhoest K., Van Thiel S., Laegreid P., Bouckaert G., Peters G., Bach T., Barbieri D., Hansen M.B., Hammerschmid G., Hintea C., Hudea A., Humphreys P., Jann W., Jokisuu J., Nakrosis V., Niklasson B., MacCarthaigh M., MacGauran A., Mendes S., Ongaro E., Painter M., Pierre J., Rubecksen K., Salminen A., Steiner R., Verschuere B., Yee H., Yesilkagit K. Joint (April 2010), COBRA database on autonomy, control and internal features of public sector organizations (open version); Collected and build by the Comparative Public Organization Data Base for Research and Analysis - network. Available: https://soc.kuleuven.be/io/cost/survey/index.htm

35. Verhoest, K., Verschuere, B.,Peters, G. and Bouckaert, G. (2004). "Controlling Autonomous Public Agencies as an Indicator of New Public Management," Management International, vol.9, pp25 - 36 .

36. Walker, R.M., (2008.) "An empirical evaluation of innovation types and organizational and environmental characteristics: towards a configuration framework," Journal of Public Administration Research and Theory vol.18, pp.591-615.

37. Wang, X. (20019. “Assessing public participation in U.S. cities," Public Performance and Management Review, vol.24, pp.322-336.

38. Wang, X.H. and Montgomery V.W. (2007). "When Public Participation in Administration Leads to Trust: An Empirical Assessment of Managers' Perceptions," Public Administration Review vol.67, pp. 265-278.

39. Wynen, J., Verhoest K., Ongaro E. and van Thiel S. 2014. "Innovation-Oriented Culture in the Public Sector: Do Managerial Autonomy and Result Control Lead to Innovation?" Public Management Review vol.16, pp.45 - 66.

40. Yamamoto, K. (2006). "Performance of semi-autonomous public bodies: linkage between autonomy and performance in Japanese agencies," Public Administration and Development vol.26, pp.35 - 44

41. Yesilkagit, K., \& van Thiel, S. (2008). "Political Influence and Bureaucratic Autonomy," Public Organization Review, vol.8, pp.137-153.

42. Zheng, Q., Luo, Y. and Wang, S.L. (2014). "Moral degradation, business ethics, and corporate social responsibility in a transitional economy," Journal of Business Ethic, vol.120, pp.405-421. 